\title{
N-methyl-D-aspartate Antagonists Prevent Kainate Neurotoxicity in Rat Retinal Ganglion Cells in vitro
}

\author{
Nikolaus J. Sucher, Elias Aizenman, ${ }^{a}$ and Stuart A. Lipton \\ Laboratory of Cellular and Molecular Neuroscience, Department of Neurology, The Children's Hospital, Beth Israel \\ Hospital, Brigham and Women's Hospital, and the Program in Neuroscience, Harvard Medical School, Boston, \\ Massachusetts 02115
}

\begin{abstract}
Under defined culture conditions, exogenous glutamate (Glu), NMDA, or an endogenous Glu-related toxin is lethal to rat retinal ganglion cells; these detrimental effects are NMDA receptor mediated because specific NMDA antagonists can prevent cellular injury. In the presence of an endogenous Glu-like toxin, $125 \mu \mathrm{M}$ kainate (KA) increases the proportion of retinal ganglion cells that die, but the toxicity (due to both $\mathrm{KA}$ and the endogenous toxin) is totally prevented by 2-amino5-phosphonovalerate (APV), a specific NMDA receptor antagonist. These findings indicate that the KA-induced portion of retinal ganglion cell death also appears to be mediated via NMDA receptors. There are at least 2 possible mechanisms for this lethal effect. In addition to KA receptors, KA could directly stimulate NMDA receptors. Alternatively, KA might activate its own specific receptor, which in turn leads to a net increase in the release of an endogenous Glu-related toxin; this endogenous substance would then activate NMDA receptors. Patch-clamp electrophysiology experiments have helped to distinguish between these possibilities. Concentrations of APV that completely block the current elicited by maximal nondesensitizing doses of NMDA exert no detectable inhibition of KA-evoked currents. Hence, at the concentrations used, it appears unlikely that KA directly activates NMDA receptors in this preparation. Furthermore, the fraction of toxicity attributed to the addition of KA can be blocked by the relatively specific non-NMDA antagonist 6-cyano-7-nitroquinoxaline-2,3-dione (CNQX). This finding is consistent with the hypothesis that KA adds an increment of toxicity in this system by directly interacting with KA receptors. Taken together, the evidence suggests that KA receptor stimulation may lead to the next efflux of additional endogenous Glu-related toxin. In turn, this Glu-related substance activates NMDA receptors and its attendant neurotoxicity.
\end{abstract}

\footnotetext{
Received Aug. 14, 1990; revised Oct. 26, 1990; accepted Nov. 2, 1990.

We thank P. A. Rosenberg for helpful discussions and J. T. Offermann, B. Cahoon, and M. Marciello for expert technical assistance. This work was supported by NIH Grants EY05477, NS07264, and HD06276, by a grant from the Sunny von Bulow Coma and Head Trauma Research Foundation, and by an Established Investigator Award from the American Heart Association to S.A.I. N.J.S. was supported by a postdoctoral fellowship from the Deutsche Forschungsgemeinschaft.

Correspondence should be addressed to Dr. Stuart A. Lipton, Department of Neurology, The Children's Hospital, Enders Building Room 350, 300 Longwood Avenue, Boston, MA 02115.

a Present address: Department of Physiology, University of Pittsburgh School of Medicine, Pittsburgh, PA 15261.

Copyright (C) 1991 Society for Neuroscience $0270-6474 / 91 / 110966-06 \$ 03.00 / 0$
}

Endogenous excitatory amino acids (EAAs) are thought to be responsible for a variety of acute neurolugical insults, including ischemia/anoxia, hypoglycemia, and trauma, as well as several chronic neurodegenerative diseases (for reviews, see Rothman and Olney, 1987; Choi, 1988a,b; Meldrum and Garthwaite, 1990). In many neuronal tissues, the predominant form of this toxicity is mediated by stimulation of the NMDA subtype of glutamate (Glu) receptor; activation of other types of Glu receptors, the kainate (KA) and quisqualate subtypes, may play a smaller role (Choi, 1987, 1988a,b; but see also Mattson et al., 1989; Sheardown et al., 1990). Nonetheless, in several preparations, the administration of exogenous $\mathrm{KA}$ can result in massive neuronal death. While in some cases $\mathrm{KA}$ appears to kill neurons directly through intense stimulation of their KA receptors (Seil et al., 1974; Bird and Gulley, 1979), in other systems the mechanism of neurotoxicity is more complex. For example, in many cases the deleterious action of $\mathrm{KA}$ requires a functionally intact excitatory input to the vulnerable population of neurons; that is, prior ablation of excitatory inputs greatly attenuates or even eliminates the neurotoxic effect of KA (Biziere and Coyle, 1978, 1979; Köhler et al., 1978; McGeer et al., 1978; Whetsell et al., 1979). These findings have led to the speculation that the direct neurotoxicity of KA may be overestimated because KA is not taken up by cells and, more importantly, because its inherent toxicity is enhanced by the release of endogenous Glu (Johnston et al., 1979; Choi, 1988b). In the current report, we use a model system of retinal cells in culture to show that the toxic effect of KA can be totally overcome with the selective NMDA antagonist 2-amino-5-phosphonovalerate (APV). In addition, patch-clamp recordings have shown that APV has no effect on the electrical response to KA, indicating that KA does not appear to stimulate directly the NMDA receptors of retinal ganglion cells. Together, these findings strengthen the hypothesis that, at least in some preparations, the lethal action of $\mathrm{KA}$ is mediated by the release of endogenous Glu-like compounds that subsequently act at the NMDA receptor.

\section{Materials and Methods}

Retinal ganglion cell culture system. Rodent retinal ganglion cells, wellcharacterized central neurons from 1-2-week-old postnatal Long-Evans rats, were identified by retrograde transport of fluorescent labels and enzymatically dissociated from the retina as we have described (Leifer et al., 1984; Lipton and Tauck, 1987). Following dissociation, the cells were rinsed with a physiological saline based on Hanks' salts (composition in mM: $\mathrm{NaCl}, 138 ; \mathrm{NaHCO}_{3}, 1 ; \mathrm{Na}_{2} \mathrm{HPO}_{4}, 0.34 ; \mathrm{KCl}, 5.36 ; \mathrm{KH}_{2} \mathrm{PO}_{4}$, $0.44 ; \mathrm{CaCl}_{2}, 1.25 ; \mathrm{MgSO}_{4}, 0.5 ; \mathrm{MgCl}_{2}, 0.5$; HEPES, 5; dextrose, 22.2; phenol red, $0.001 \% \mathrm{v} / \mathrm{v}$; adjusted to $\mathrm{pH} 7.2$ with $0.3 \mathrm{M} \mathrm{NaOH}$ ). The retinas were then mechanically dispersed, and $\sim 100-\mu$ l volumes of the 
resulting suspension were plated at an initial density of $\sim 500$ cells per $\mathrm{mm}^{2}$ onto poly-L-lysine-coated glass coverslips previously affixed to the hollow bottom of $35 \times 10$-mm tissue-culture dishes with Sylgard (Dow Corning, Midland, MI). The cell culture medium was based upon Eagle's minimum essential medium (MEM), except that it was nominally magnesium-free to facilitate the occurrence of NMDA receptor-mediated toxicity (Hahn et al., 1988). The medium was supplemented with $0.7 \%$ methylcellulose (w/v), $1 \mu \mathrm{g} / \mathrm{ml}$ gentamicin, $16 \mathrm{~mm}$ dextrose, $2 \mathrm{~mm}$ glutamine, $5 \%$ rat serum $(\mathrm{v} / \mathrm{v})$, and a concentration of $\mathrm{CaCl}_{2}$ of 1.8 or 10 $\mathrm{mM}$, with the higher value to enhance excitatory amino acid toxicity in this preparation (Hahn et al., 1988). In some experiments, up to 250 $\mu \mathrm{M}$ glycine was present in the culture medium as measured by HPI.C. analysis; however, glycine did not affect the results reported here. Cultures were incubated at $37^{\circ} \mathrm{C}$ in a humidified atmosphere of $5 \% \mathrm{CO}_{2} \prime$ $95 \%$ air.

Electrophysiology experiments. Whole-cell recordings (Hamill et al., 1981) were performed with patch electrodes on rat retinal ganglion cells as described in detail by this laboratory (Lipton and Tauck, 1987; Aizenman et al., 1988, 1989; Karschin et al., 1988). Prior to recording, the cell cultures were incubated for 4-24 $\mathrm{hr}$ in MEM. During recording sessions, coverslips were continuously superfused at $\sim 1 \mathrm{ml} / \mathrm{min}$ in nominally magnesium-free Hanks' solution with $2.5 \mathrm{mM} \mathrm{CaCl}_{2}$ and $1 \mu \mathrm{M}$ glycine, a coagonist at the NMDA receptor. All drugs were diluted in this Hanks' solution and applied by pneumatic pipette. In order to avoid confusion due to the release of endogenous substances from one neuron onto another, only solitary retinal ganglion cells (i.e., cells lacking synaptic connections with other neurons) were recorded from. The patch pipettes contained (in $\mathrm{mM}$ ) $\mathrm{CsCl}, 120$; tetraethylammonium (TEA)-Cl, $20 ; \mathrm{MgCl}_{2}, 2 ; \mathrm{CaCl}_{2}, 1$; EGTA, 2.25; HEPES-NaOH, 10 (adjusted to $\mathrm{pH}$ 7.2). The temperature was maintained at $35^{\circ} \mathrm{C}$, and the whole-cell current responses were filtered at $500 \mathrm{~Hz}$ with a Bessel characteristic.

Assessment of neurotoxicity. For the toxicity experiments, the culture medium was composed of the nominally magnesium-free MEM listed above. Under our culture conditions, retinal ganglion cells are susceptible to NMDA receptor-mediated toxicity in the presence of elevated extracellular $\mathrm{Ca}^{2+}$ (Hahn et al., 1988). This toxicity manifests itself in the presence of exogenous Glu $(10 \mu \mathrm{M}$ to $1 \mathrm{mM})$, NMDA $(200 \mu \mathrm{M})$, or an endogenous Glu-like substance that could be detected in densely plated cultures (Hahn et al., 1988; Levy and Lipton, 1990; Levy et al., 1990). HPLC assays revealed that the endogenous level of Glu in these cultures was about $20 \mu \mathrm{M}$, which is itself toxic in this this culture system under these conditions (Rosenberg and Aizenman, 1989; Levy and Lipton, 1990; Levy et al., 1990); thus, the endogenous Glu-like toxin may have been Glu itself.

In the present experiments, the control treatments contained low (1.8 mм) $\mathrm{CaCl}_{2}$ to minimize death, while sibling test cultures contained high (10 $\mathrm{mM}) \mathrm{CaCl}_{2}$ to promote toxicity mediated at the NMDA receptor by the endogenous Glu-like compound (Hahn et al., 1988; Levy and Lipton, 1990; Levy et al., 1990). Added to the medium containing high concentrations of $\mathrm{Ca}^{2+}$ at the time of plating were the selective NMDA antagonist APV $(200 \mu \mathrm{M})$, the relatively selective non-NMDA antagonist 6-cyano-7-nitroquinoxaline-2,3-dione (CNQX; $10 \mu \mathrm{M}$ ), and/or KA (125 $\mu \mathrm{M})$. The cell cultures were incubated for $18-24 \mathrm{hr}$ after their preparation at $37^{\circ} \mathrm{C}$ in a humidified atmosphere of $5 \% \mathrm{CO}_{2} / 95 \%$ air. Neuronal survival was then scored by counting retinal ganglion cells displaying uptake and cleavage of the fluorescent dye fluorescein diacetate to fluorescein, as described by this laboratory (for color photographs, see Hahn et al., 1988, their Fig. 1). Results are based upon experiments conducted in at least quadruplicate on 3 separate occasions. Prior to statistical analysis, data were normalized so that for any one experiment the mean number of surviving retinal ganglion cells in control lowcalcium medium was equal to $100 \%$.

Reagents. Tissue culture reagents were purchased from Sigma Chemical Company and from Gibco. D-(-)-2-Amino-5-phosphonovalerate (APV) was obtained from Cambridge Research Biochemicals; 6-cyano7-nitroquinoxaline-2,3-dione (CNQX) was obtained from Tocris Neuramin (Essex, UK). All other reagents were purchased from Sigma.

\section{Results}

Patch-clamp recordings of EAA agonists and antagonists

Electrophysiological experiments were performed to ensure that the drugs used in the subsequent toxicity studies were truly specific in this preparation. Figure $1 \mathrm{~A}$ shows that the peak current evoked by $200 \mu \mathrm{M}$ NMDA is only partially ( $\sim 20 \%)$ inhib- ited by $10 \mu \mathrm{M}$ CNQX; the steady-state current is not inhibited by CNQX at all ( $n=5$ retinal ganglion cells). However, as illustrated in Figure $1 B$, this NMDA response can be completely blocked by $200 \mu \mathrm{M}$ APV. In contrast, the response to $125 \mu \mathrm{M}$ $\mathrm{KA}$, which patch-clamp recording in this preparation has shown to be totally insensitive to APV (Aizenman et al., 1988), is nearly completely (>90\%) abrogated by $10 \mu \mathrm{M}$ CNQX (Fig. 1C). Figure $1 D$ shows that CNQX antagonizes the response to Glu to a substantial degree, while the addition of APV blocks only a small remaining fraction of the current; these findings confirm other reports that the non-NMDA component of the response in this preparation is considerably larger than the NMDA contribution (Aizenman et al., 1988; Karschin et al., 1988). Finally, one could argue that the ability of KA to elicit NMDA receptor-activated current would be observed only in the absence of extracellular $\mathrm{Mg}^{2+}$, and the presence of $\mathrm{Mg}^{2+}$ in the standard physiological saline used in previous experiments with KA (Aizenman et al., 1988 ) would have blocked the NMDA receptor-operated channels. Therefore, the absence of antagonism of the KA-activated current by APV could be due to prior blockade by extracellular $\mathrm{Mg}^{2+}$ of the NMDA component of the response to KA. However, even with extracellular $\mathrm{Mg}^{2+}$ removed from the bath, APV still had no effect on the KA-evoked current (Fig. $1 E$ ). Thus, at least in this preparation, $125 \mu \mathrm{M} \mathrm{KA}$ does not appear to evoke directly an NMDA receptor-activated current.

\section{Toxicity of $K A$ and $N M D A$ agonists}

The data of Figure 2, columns 1 and 2, confirm the finding that an endogenous Glu-like compound in these cultures is toxic to retinal ganglion cells in the presence of elevated extracellular $\mathrm{Ca}^{2+}$ (Hahn et al., 1988). This form of endogenous Glu toxicity is mediated at the NMDA subtype of receptor because $200 \mu \mathrm{M}$ APV completely prevents the death (Hahn et al., 1988; Levy and Lipton, 1990; Levy et al., 1990). Figure 2, column 3, shows that the addition of $125 \mu \mathrm{M}$ KA produces an incremental degree of retinal ganglion cell killing. In these experiments, the inclusion of $200 \mu \mathrm{M} \mathrm{APV}$ in the culture medium completely blocks the toxicity of the endogenous Glu-like substance as well as the additional KA-induced death (column 4). In contrast, only the $\mathrm{KA}$ contribution to toxicity is blocked by $10 \mu \mathrm{M}$ CNQX (cf. columns 2, 5). These results show that the KA component of excitotoxicity can be prevented by the non-NMDA antagonist CNQX while both the KA and the endogenous components can be completely eliminated by the NMDA-specific antagonist APV.

\section{Discussion}

In posinatal ral retinal cultures, KA sets into motion a series of calcium-dependent steps that leads in a delayed fashion to the neurotoxicity of the ganglion cells. In a simple model, KA could in theory exert a toxic action on retinal ganglion cells in this preparation by a variety of alternative pathways. Let us consider in turn the evidence for and against each pathway. KA might activate $\mathrm{KA}$-specific receptors to initiate neuronal toxicity directly. However, the complete prevention of the deleterious effect of KA by specific NMDA antagonists suggests that KA must somehow activate NMDA receptors in order to precipitate a lethal outcome. Alternatively, then, KA might directly interact with NMDA receptors, which in turn produce cell death (Hahn et al., 1988). Nevertheless, the patch-clamp electrophysiology data show that the NMDA receptor antagonist APV does not decrease the electrical responses to KA in these neurons. This result suggests, at least in this preparation at the concentrations 
A
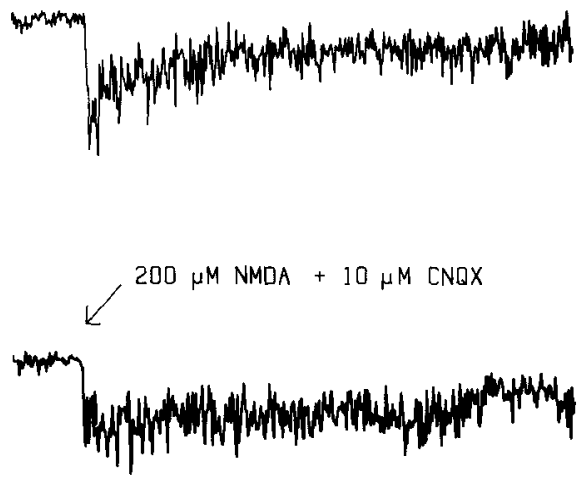

$40 \mathrm{pA}$

$983 \mathrm{~ms}$

$V H=-60 m V$

C

$125 \mu M$ Kaimate

Figure 1. Electrophysiological effects of EAA agonists and antagonists on postnatal rat retinal ganglion cells. Whole-cell current recordings with a patch electrode were obtained at a holding potential of $V_{H}=-60 \mathrm{mV}$. Drugs were applied for the duration indicated by the broken line above the traces. Each panel presents a typical recording from a separate ganglion cell. $A$, Responses to NMDA $(200 \mu \mathrm{M})$ and to NMDA + CNQX $(10 \mu \mathrm{M}) . B$, Responses to NMDA $(200 \mu \mathrm{M})$ and to NMDA + APV (200 $\mu \mathrm{M}) . C$, Responses to KA (125 $\mu \mathrm{M})$ and to $\mathrm{KA}+\mathrm{CNQX}(10 \mu \mathrm{M}) . D$. Responses to Glu (200 $\mu \mathrm{M})$, to Glu + CNQX (10 $\mu \mathrm{M})$, and to Glu + CNQX $(10 \mu \mathrm{M})+$ APV $(200 \mu \mathrm{M}) . E$, Responses to KA (125 $\mu \mathrm{M})$, to $\mathrm{KA}+\operatorname{APV}(200 \mu \mathrm{M})$, and to NMDA $(200 \mu \mathrm{M})$ in the same retinal ganglion cell. See Results for explanation.

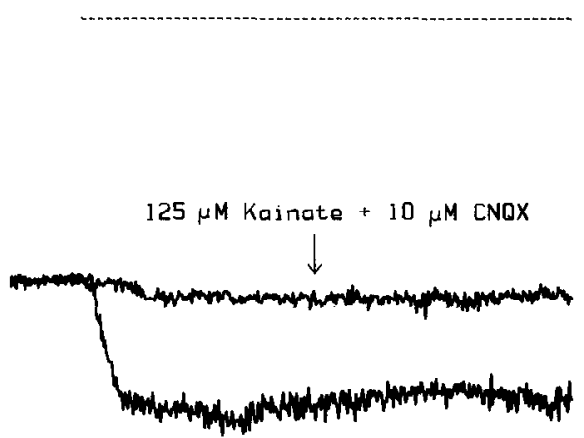

$150 \mathrm{pA}$

$983 \mathrm{~ms}$

E

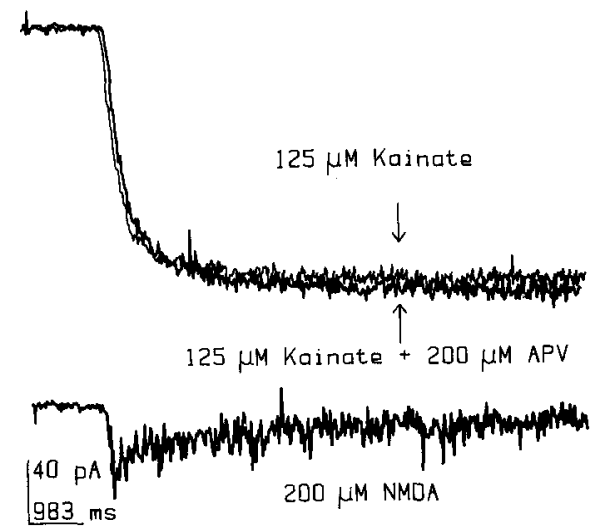

$983 \mathrm{~ms}$
B $200 \mu M N M D A$

$40 \mathrm{pA}$

983 ms

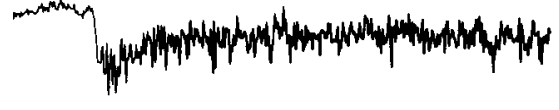

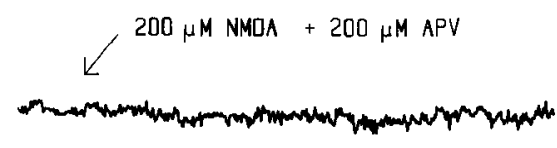

D

$200 \mu M$ Glutamate

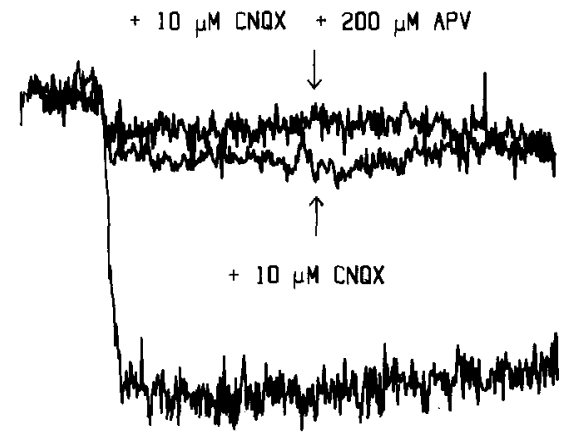

50 pA

$983 \mathrm{~ms}$ 
under consideration, that KA docs not dircctly clicit an NMDA response. The final possibility is that KA leads to the increase of an endogenous substance that in turn evokes NMDA receptor activation. The findings of the present study are consistent with the latter hypothesis and with other results showing that KA increases the net efflux of an endogenous Glu-related compound in several preparations (see below). Our data show that this endogenous substance contributes to NMDA receptor-mediated neurotoxicity in the retinal ganglion cell neuronal population. Furthermore, the results suggest that it is not KA itself but only the endogenous compound that is lethal because APV, which totally prevented neuronal death, should not block a direct toxic effect of KA.

Recently, Michaels and Rothman (1990) and Koh et al. (1990) have raised the alternative hypothesis, outlined above, that a component of the KA (or quisqualate) response could be due to dircet activation of NMDA receptors; in this manner, thesc non-NMDA agonists could directly produce delayed-onset cell death (in the case of KA; Michaels and Rothman, 1990) or acute neuronal swelling (in the case of quisqualate; Koh et al., 1990). However, at least in our preparation, this alternative would appear to be less likely because of the pharmacological evidence gathered in patch-clamp recordings from rat retinal ganglion cells. These recordings have shown that KA (and quisqualate) responses are completely unaffected by NMDA receptor antagonists, such as APV, at concentrations that are sufficient to block totally the electrical response to a maximal nondesensitizing dose of NMDA (Aizenman et al., 1988; Karschin et al., 1988). Given these data, it is difficult to envision a scenario whereby KA would be capable of stimulating NMDA receptors directly, even to a small degree, but the response would be not at all influenced by substantial concentrations of APV. Taken together, the patch-clamp recordings and the toxicity studies of retinal ganglion cells suggest that, rather than acting as a direct toxin, $\mathrm{KA}$ increases release of an endogenous substance that in turn leads to neuronal death, at least in this preparation (see also the discussion of CNQX effects, below, and Balázs et al., 1990).

The mechanisms whereby KA might increase Glu or a Glulike compound have been addressed in other recent reports. In several tissues, KA causes a net release of endogenous Glu and aspartate (Asp; Ferkany et al., 1982; Krespan et al., 1982; Ferkany and Coyle, 1983a,b; Pastuszko et al., 1984; Poli et al., 1985). In some cases, KA may enhance synaptic release of EAAs by stimulating presynaptic receptors (Cox and Bradford, 1978; Ferkany et al., 1982; Krespan et al., 1982; Collins et al., 1983; Coyle, 1983; Ferkany and Coyle, 1983a; Pastuszko et al., 1984; Young et al., 1988). However, there is also evidence that KAinduced blockade of Glu/Asp uptake can be a primary event in producing an increase in extracellular Glu and $\Lambda$ sp (Lakshamanan et al., 1974; McGeer et al., 1978; Johnston et al., 1979; Krespan and Padmanaban, 1982; Pastuszko et al., 1984). Along these lines, one recent report in cerebrocortical synaptosomes presented evidence for a slow leak of Glu or Asp and showed that $\mathrm{KA}$ could potentiate this $\mathrm{Ca}^{2+}$-independent net efflux of Glu and Asp apparently by inhibiting reuptake; in that system, $\mathrm{KA}$ did not affect $\mathrm{Ca}^{2+}$-dependent synaptic release of endogenous Glu (Pocock et al., 1988).

In our preparation, $10 \mu \mathrm{M} C \mathrm{NQX}$ does not inhibit the steadystate NMDA current but nearly totally abolishes the KA-evoked current. Recent reports have shown that the partial inhibition of NMDA-induced current by CNQX in other preparations (and of the peak NMDA current in retinal ganglion cells) is mediated

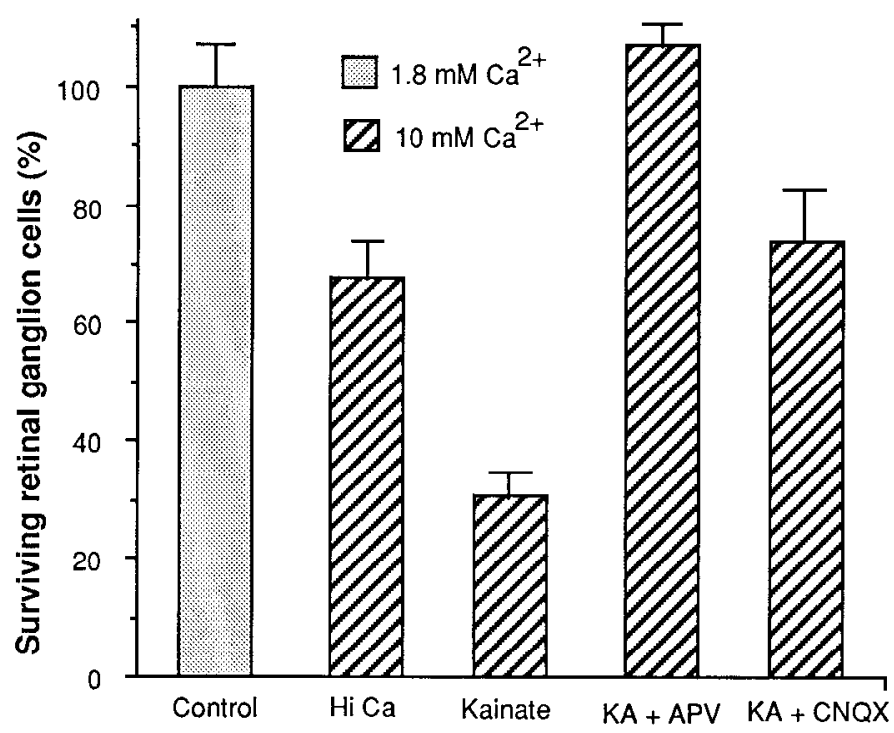

Contains endogenous glutamate; nominally $\mathrm{Mg}$ free

Figure 2. Relative contributions to neurotoxicity of an endogenous Glu-like toxin and of exogenous KA. Mean and SEM of surviving retinal ganglion cells after $1 \mathrm{~d}$ in culture are shown for the following groups: control (column 1; extracellular $\left[\mathrm{Ca}^{2+}\right]=1.8 \mathrm{~mm}$ ); high calcium (column 2; extracellular $\left.\left[\mathrm{Ca}^{2+}\right]=10 \mathrm{mM}\right) ; 125 \mu \mathrm{M} \mathrm{KA}$ in the presence of high $\mathrm{Ca}^{2+}$ (column 3); $125 \mu \mathrm{M} \mathrm{KA}+\mathrm{APV}(200 \mu \mathrm{M})$ in the presence of high $\mathrm{Ca}^{2+}$ (column 4); and $125 \mu \mathrm{M} \mathrm{KA}+\mathrm{CNQX}(10 \mu \mathrm{M})$ in the presence of high $\mathrm{Ca}^{2+}$ (column 5). Statistical testing with an ANOVA followed by a Scheffé multiple comparison of means revealed the following rank order of results $(P<0.01$ for each comparison): [Control] $=[\mathrm{KA}+$ $\mathrm{APV}]>[\mathrm{Hi} \mathrm{Ca}]-[\mathrm{K} \Lambda+\mathrm{CNQX}]>[\mathrm{K} \Lambda]$

at the glycine binding site of the NMDA receptor (Yamada et al., 1989). However, the presence of up to $250 \mu \mathrm{M}$ glycine in our culture medium did not detract from the protective effect of CNQX against KA toxicity. Under these conditions, CNQX does not block NMDA responses at all. Taken together, these findings suggest that, in our culture system, CNQX prevents the toxic effect of exogenously added KA by antagonism at the KA receptor. These results also make it unlikely that KA toxicity is mediated by direct activation of NMDA receptors because CNQX, acting at the KA receptor and not at the NMDA receptor, can block KA-induced cell death. Moreover, in retinal cultures it would appear more likely that KA-enhanced release of an endogenous Glu-like molecule, rather than block of reuptake, is responsible for the NMDA receptor-mediated toxicity because CNQX might not be expected to affect the reuptake mechanism.

The importance of the present study is its clear demonstration under the relatively well-controlled conditions of cell culture that KA-induced neurotoxicity can result, at least in one preparation, from an indirect effect on the NMDA receptor; the lethal action of KA appears to be mediated by the release of an endogenous Glu-related compound that subsequently activates NMDA receptors. Although the effects of KA may vary from preparation to preparation, evidence that our findings may possibly he generalized to other systems is beginning to mount. For example, in dissociated neonatal hippocampal cultures, KA damage was blocked by dibenzocyclohepteneimine (MK-801; Michaels and Rothman, 1990), a relatively selective antagonist of NMDA receptor-operated channels (Huettner and Bean, 1988; 
Karschin et al., 1988). Also, in cultured cerebellar granule cells, NMDA antagonists blocked a deleterious component of KA action (Balázs et al., 1990). In addition, in the intact chick retina maintained in vitro, APV partially blocked KA-induced toxicity (Olney et al., 1986). In a sense, the indirect toxic action of KA is somewhat surprising in light of the fact that the KA-evoked current is much larger than the NMDA-activated ionic current in our cultured retinal ganglion cells (cf. Fig. 1). However, one explanation for this apparent paradox involves the calciumdependent nature of the predominant form of excitotoxicity (Choi, 1985, 1987; Garthwaite et al., 1986; Hahn et al., 1988): because only NMDA receptor-operated channels, and not the channels directly activated by $\mathrm{KA}$, are permeable to $\mathrm{Ca}^{2+}$ (MacDermott et al., 1986; Mayer and Westbrook, 1987; Mayer et al., 1987), the NMDA contribution to toxicity might be expected to outweigh that of KA. Although KA would be expected to depolarize retinal ganglion cells and thus trigger $\mathrm{Ca}^{\text {?+ }}$ entry via voltage-sensitive calcium channels (Sucher et al., 1990; Weiss et al., 1990), activation of this pathway alone may not be sufficient to elicit neuronal cell death, at least in this preparation. Hence, an additional component of EAA neurotoxicity mediated directly by NMDA receptor activation appears to be necessary for retinal ganglion cell death in vitro.

\section{References}

Aizenman E, Frosch MP, Lipton SA (1988) Responses mediated by excitatory amino acid receptors in solitary retinal ganglion cells from rat. J Physiol (Lond) 396:75-91.

Aizenman E, Lipton SA, Loring RH (1989) Selective modulation of NMDA responses by reduction and oxidation. Neuron 2:1257-1263.

Balázs, R, Hack H, Jørgensen OS (1990) Interactive effects involving different classes of excitatory amino acid receptors and the survival of cerebellar granule cells in culture. Int J Neurosci 8:347-359.

Bird SJ, Gulley RL (1979) Evidence against a presynaptic mechanism for kainate neurotoxicity in the cochlear nucleus. Neurosci Lett 15 : $55-60$.

Biziere K, Coyle JT (1978) Influence of cortico-striatal afferents on striatal kainic acid neurotoxicity. Neurosci Lett 8:303-310.

Biziere K, Coyle JT (1979) Effects of cortical ablation on the neurotoxicity and receptor binding of kainic acid in striatum. J Neurosci Res 4:383-398.

Choi DW (1985) Glutamate neurotoxicity in cortical cell culture is calcium dependent. Neurosci Lett 58:293-297.

Choi DW (1987) Ionic dependence of glutamate neurotoxicity in cortical cell culture. J Neurosci 7:369-379.

Choi DW (1988a) Calcium-mediated neurotoxicity: relationship to specific channel types and role in ischemic damage. Trends Neurosci 11:465-469.

Choi DW (1988b) Glutamate neurotoxicity and diseases of the nervous system. Neuron 1:623-634.

Collins GG, Anson J, Surtees L (1983) Presynaptic kainate and $N$-methyl-D-aspartate receptors regulate excitatory amino acid release in the olfactory cortex. Brain Res 265:157-159.

Cox DWG, Bradford HF (1978) Uptake and release of excitatory amino acid neurotransmitters. In: Kainic acid as a tool in neurobiology (McGeer EG, Olney JW, McGeer PL, eds), pp 71-93. New York: Raven.

Coyle JT (1983) Neurotoxic action of kainic acid. J Neurochem 41: $1-11$.

Ferkany JW, Coyle JT (1983a) Evoked release of aspartate and glutamate: disparities between prelabelling and direct measurement. Brain Res 278:279-282.

Ferkany JW, Coyle JT (1983b) Kainic acid selectively stimulates the release of endogenous excitatory acidic amino acids. J Pharmacol Exp Ther 225:399-406.

Ferkany JW, Zaczek R, Coyle JT (1982) Kanic acid stimulates excitatory amino acid neurotransmitter release at presynaptic receptors. Nature 298:757-759.

Garthwaite G, Hajós F, Garthwaite J (1986) Ionic requirements for neurotoxic effects of excitatory amino acid analogues in rat cerebellar slices. Neuroscience 18:437-447.

Hahn JS, Aizenman E, Lipton SA (1988) Central mammalian neurons normally resistant to glutamate toxicity are made sensitive by elevated extracellular $\mathrm{Ca}^{2+}$ : toxicity is blocked by the $N$-methyl-D-aspartate antagonist MK-801. Proc Natl Acad Sci USA 85:6556-6560.

Hamil OP, Sigworth FJ, Neher E, Sakmann B (1981) Improved patchclamp techniques for high-resolution current recording from cells and cell-free membrane patches. Pfluegers Arch 391:85-100.

Huettner JE, Bean BP (1988) Block of $N$-methyl-D-aspartate-activated current by the anticonvulsant MK-801: selective binding to open channels. Proc Natl Acad Sci USA 85:1307-1311.

Johnston GA, Kennedy SME, Twitchen B (1979) Action of the neurotoxin kainic acid on high affinity uptake of $\mathbf{L}$-glutamic acid in rat brain slices. J Neurochem 32:121-127.

Karschin A, Aizenman E, Lipton SA (1988) The interaction of agonists and noncompetitive antagonists at the excitatory amino acid receptors in rat retinal ganglion cells. J Neurosci 8:2895-2907.

Koh J-Y, Goldberg MP, Hartley DM, Choi DW (1990) Non-NMDA receptor-mediated neurotoxicity in cortical culture. J Neurosci 10: 693-705.

Köhler C, Schwarcz R, Fuxe K (1978) Perforant path transections protect hippocampal granule cells from kainate lesions. Neurosci Lett 10:241-246.

Krespan B, Berl S, Nicklas WJ (1982) Alteration in neuronal-glial metabolism of glutamate by the neurotoxin kainic acid. J Neurochem 38:509-518.

Lakshamanan J, Padmanaban G (1974) Effect of some strong excitants of central neurons on the uptake of glutamate and aspartate by synaptosomes. Biochem Biophys Res Commun 58:690-698.

Leifer D, Lipton SA, Barnstable CJ, Masland RH (1984) Monoclonal antibody to Thy-1 enhances regeneration of processes by rat retinal ganglion cells in culture. Science 224:303-306.

Levy DI, Lipton SA (1990) Comparison of delayed administration of competitive and uncompetitive antagonists in preventing NMDA receptor-mediated neuronal death. Neurology 40:852-855.

Levy DI, Sucher N.I, Lipton SA (1990) Redox modulation of NMDA receptor-mediated toxicity in mammalian central neurons. Neurosci Lett 1 10:291-296.

Lipton SA, Tauck DL (1987) Voltage-dependent conductances of solitary ganglion cells dissociated from the rat retina $\mathbf{J}$ Physiol (Lond) 385:361-391.

MacDermott AB, Mayer ML, Westbrook GL, Smith SJ, Baker JL (1986) NMDA-receptor activation increases cytoplasmic calcium concentration in cultured spinal cord neurons. Nature 321:519-522.

Mattson MP, Guthrie PB, Hayes BC, Kater SB (1989) Roles for mitotic history in the generation and degeneration of hippocampal neuroarchitecture. J Neurosci 9:1223-1232.

Mayer ML, Westbrook GL (1987) Permeation and block of $N$-methylD-aspartic acid receptor channels by divalent cations in mouse cultured central neurones. I Physiol (Lond) 394:501-527.

Mayer ML, MacDermott AB, Westbrook GL, Smith SJ, Barker JL (1987) Agonist- and voltage-gated calcium entry in cultured mouse spinal cord neurons under voltage clamp measured using arsenazo III. J Neurosci 7:3230-3244.

McGeer EG, McGeer PL, Singh K (1978) Kainate-induced degeneration of neostriatal neurons: dependency upon corticostriatal tract. Brain Res 139:381-383.

Meldrum B, Garthwaite J (1990) Excitatory amino acid neurotoxicity and neurodegenerative disease. Trends Pharmacol Sci 11:379-387

Michaels RL, Rothman SM (1990) Glutamate neurotoxicity in vitro: antagonist pharmacology and intracellular calcium concentrations. $J$ Neurosci 10:283-292.

Olney JW, Price MT, Fuller TA, Labruyere J, Samson L, Carpenter M, Mahan K (1986) The anti-excitotoxic effects of certain anesthetics, analgesics and sedative-hyponotics. Neurosci Lett 68:29-34.

Pastuszko A, Wilson DF, Erecinska M (1984) Effects of kainic acid in rat brain synaptosomes: the involvement of calcium. J Neurochem 43:747-754

Pocock JM, Murphie HM, Nicholls DG (1988) Kainic acid inhibits the synaptosomal plasma membrane glutamate carrier and allows glutamate leakage from the cytoplasm but does not affect glutamate exocytosis. J Neurochem 50:745-751.

Poli A, Contestabile A, Migani P, Rossi L, Rondelli C, Virgili M, Bissoli R, Barnabei O (1985) Kainic acid differentially affects the synapto- 
somal release of endogenous and exogenous amino acid neurotransmitters. J Neurochem 45:1677-1686.

Rosenberg P, Aizenman E (1989) Hundred-fold increase in neuronal vulnerability to glutamate toxicity in astrocyte-poor cultures of rat cerebral cortex. Neurosci Lett 103:162-168.

Rothman SM, Olney JW (1987) Excitotoxicity and the NMDA receptor. Trends Neurosci 10:299-302.

Seil FJ, Blank NK, Leiman AL (1974) Toxic effects of kainic acid on mouse cerebellum in tissue culture. Brain Res 161:253-265.

Sheardown MJ, Nielsen EO, Hansen AJ, Jacobsen P, Honoré T (1990) 2,3-Dihydroxy-6-nitro-7-sulfamoyl-benzo(F)quinoxaline: a neuroprotectant for cerebral ischemia. Science 247:571-574.

Sucher NJ, Wong LA, Lipton SA (1990) Redox modulation of NMDA receptor-mediated $\mathrm{Ca}^{2+}$ flux in mammalian central neurons. NeuroReport 1:29-32.
Weiss IH, Hartley DM, Koh J, Choi DW (1990) The calcium channel blocker nifedipine attenuates slow excitatory amino acid neurotoxicity. Science 247:1474-1477.

Whetsell WO, Ecob-Johnston MS, Nicklas WJ (1979) Studies of kainate-induced caudate lesions in organotypic tissue cultures. In: Advances in neurology, Vol 23 (Wexler NS, Barbeau A, eds), pp 645654. New York: Raven.

Yamada KA, Dubinsky JM, Rothman SM (1989) Quantitative physiological characterization of a quinoxalinedione non-NMDA receptor antagonist. J Neurosci 9:3230-3236.

Young AMJ, Crowder JM, Bradford HF (1988) Potentiation by kainate of excitatory amino acid release in striatum: complementary in vivo and in vitro experiments. J Neurochem 50:337-345. 